\title{
Canaan Dog
}

National Cancer Institute

\section{Source}

National Cancer Institute. Canaan Dog. NCI Thesaurus. Code C54049.

The Canaan Dog is a sturdy, medium-sized, squarely proportioned herding dog with a bushy tail carried curled over the back when the dog is alert. Ears have a broad base, rounded tip, and are set high. The straight, harsh, double coat lies flat. It comes in solid black, brown, and white, or in a patched pattern of white with black or brown. Height: 1924 inches (48-61 cm.) Weight: 35-55 pounds (16-25 kg.) 